\title{
THE FUNCTION OF REPETITION AND CONTRADICTION IN THE PARADIGM OF THE JUDGES (2:11-19)
}

\author{
Elie Assis \\ Bible Department \\ Bar Ilan University
}

\begin{abstract}
The Book of Judges is unique in that it includes in its inception a schematic description of the pattern of the narratives of the Judges that reoccurs throughout the book. However, the description of the paradigmatic pattern is complex: it contains repetitions, inconsistencies, and even a significant contradiction. These textual phenomena have been typically explained in diachronic and synchronic readings. This article claims that these phenomena are literary devices to create multifaceted meaning.
\end{abstract}

Keywords: Transgression; Repetitions; Contradictions; Inconsistencies;

Diachronic; Synchronic

\section{Introduction}

The first part of the book consists of two separate prologues: the first, is from 1:1-2:10, and the second, from 2:11 - 3:6. The former, describes Israel's failure to complete the conquest of the Land, for which God's messenger reproaches them (2:1-5). The latter, describes the people's sin of idolatry $(2: 11-3: 6)$. The second prologue, includes a paradigmatic model of the Judges narratives that comprise the main part of the book. The two introductions form a logical sequence: the first, looks back to Joshua's time, while the second, describes the period that follows the first - the era of the judges. This aims to expose the literary and theological function of inconsistencies within the text of the model (2:22-19).

\section{The Paradigmatic Model of the Judges Narratives}

The second prologue of the Book of Judges (2:11-3:6) opens with a schematic description of the pattern that reoccurs throughout the Judges narratives (3:7-16:31). This model comprises three stages: ${ }^{1}$

1. The people sin by serving idols (2:11-13)

2. God grows angry at Israel and punishes them (2:14-15)

3. God saves them by sending a savior to rescue Israel (2:16-19).

\footnotetext{
For a broad discussion of the pattern throughout the book, see O'Connell (1996: 19-57). On the model's significance, see Trompf (1979: 213-229).
} 
Some commentators argue that there are four stages: sin, punishment, repentance, and salvation (e.g., Soggin 1981:43; Schneider 2000:32). Effectively, however, no such "repentance" actually appears in the book's introduction or in the narratives themselves; the only narrative that describes the people's repentance before God's sending of a saviour is the story of Jephthah $(10: 10,15) .^{2}$ Others specify that the fourth stage is crying out to God (Exum 1990:411-412), and the people indeed cry out to God in all the Judges narratives except Samson's, where the people neither repent nor cry out for help. Intriguingly, even though the people cry out to God in most of the Judges narratives, there is no mention of this stage in the paradigmatic model (Greenspahn 1986:385-396). Some explain that the expression "for the Lord would be moved to pity by their groaning" (18) refers to the people's supplications (O'Connell 1996:40). But this is not the plain meaning of the expression; "their groaning" means their groans and misery at their suffering and does not necessarily imply that they cried out to God.

This fact sheds new light on the objective of this prologue. Most scholars hold that its purpose is to describe Israel's relationship with God (Moore 1895:63). ${ }^{3}$ The people's sin moves God to anger and punishment, and, if they follow in God's ways, God saves them. The people's relapse into evil is what creates the cyclical structure of the book. It is difficult to argue with this obvious explanation. Yet, if this is the primary objective of the introduction, why does the model omit a detail that appears in almost all the Judges narratives: that salvation follows the people's crying out to God? A more suitable model for this approach would be one in which repentance causes a change in God's attitude towards the people, as commentators are inclined to perceive in the text, even though this component is not there. Given the lack of this significant theological component in the paradigmatic model - especially considering that the redactor could have easily added these words (especially in light of the prevalent scholarly approach that the authors and redactors of Judges were inclined to make emendations and additions to the text) we must seek out a more accurate description of the model's objective.

The most obvious effect the introduction generates for the reader is that of "spoiler" - presenting the pattern at the outset prevents any real suspense in the narratives themselves, as the ending is already known (Webb 1987:120). Once the reader has read the introduction, he or she already knows how every episode will end, and there is no

2 This is accepted by most scholars and reinforced lately by Hoyt (2012:143-158) who dedicated an entire study to the lack of repentance in Judges. Recently, Sergev Frolov and Mikhail Stetckevich have claimed that the act of crying out in the narratives of the Judges (except that of Samson) means to repent, see: Frolov and Stetckevich (2019:12-139). They assume that, since the crying out reverses the abandonment of God, crying out to God means the opposite - returning to God (132). It is difficult to accept this understanding. If the meaning is "to repent", why did the author avoid using the root שוב? Moreover, there is no difficulty in interpreting that the people cried out to God and God saved them, but in crying to God they did not repent crying to God and abandoning God do not have to be exact opposites.

3 Similarly, Webb (1987:120) points out the summarising nature of the paradigmatic model, but claims that vv. 20-22 provide new information about the people's sins, which is not mentioned before, not even in the first introduction. Lindars (1995:91) believes that because the narratives were artificially arranged in a consecutive historical sequence; the historian felt a need to provide a historical framework for the era. On the ideology of the redactive framework of the book, see Soggin 1981:42-43. Gillmayer-Bucher (2009:687-702) points out the complex relationship between the model at the beginning of the book and its various manifestations in all the Judges narratives. She believes that the relationship between the model at the beginning of the book and in each of the narratives is one of dialogue and development and observes that only Othniel's leadership follows this model while the rest of the models gradually deviate further from the introductory model, which leads her to conclude that, as the book progresses, the judges' contribution grows weaker. 
suspense as to whether God and the people will be reconciled. It is no coincidence that this is a relatively rare phenomenon in literature in general and that there are no other such models presented in any other biblical work. Elsewhere, I have claimed that, by the time the reader reaches the Judges narratives, he or she already knows how it will end: this form of leadership will not be successful (Assis 2005:243-244). Thus, from the beginning of the work, the reader already knows that each judge will manage to save Israel from the enemy, but that this judge will fail to bring lasting religious and political stability. This lack of suspense is significant and can be ascribed to an author who wished to diffuse any potential narrative drama in the Judges narratives. With each episode, the reader is already moved to consider what kind of system of government will prevent this downward spiral of God's relationship with Israel. This introduction already anticipates the next system, which will be presented in the Book of Samuel: the monarchy. If so, we can understand why the prologue does not mention how the people cry out to God. Its objective is not merely a theological description of God's relationship with Israel; it is to depict the lack of religious stability that leads to political instability. The era of the Judges is characterized by instability and circularity. The prologue's objective is to describe this circularity to move the reader to contemplate possible alternatives to this unstable system of government. The introduction's placement invites the reader to notice the disadvantages of the system as the narratives progress; in this way, the reader becomes part of the process that unfolds and eventually culminates in the institution of the monarchy in the Book of Samuel. After the process that the reader undergoes, is exposed, this was the introduction's objective in the first place.

\section{Repetitions and Inconsistences in the Paradigmatic Model}

The schematic description of the era of the judges is complex. In each of the three stages of sin, punishment, and salvation, there is repetition and even contradiction.

1. The description of $\sin$ in $v .13$ repeats $11 \mathrm{~b}$ and $12 \mathrm{a}$.

2. The description of the punishment in v. 14 appears twice: in 14a and 14b.

3. The description of the salvation appears twice: once in vv. 16-17 and a second time in vv. 18-19.

Scholars, particularly those of older schools, tend to see these repetitions as an indication of multiple sources and redaction, and there have been numerous attempts to split up the verses into different sources. ${ }^{4}$ More recent scholars, however, ascribe less significance

\footnotetext{
Regarding the repeated descriptions of the sin, Moore (1895:79) concludes that as v. 12 is Deuteronomistic, v. 13 should be attributed to E. Regarding the repeated descriptions of the punishment in v. 14 (p. 71), Moore ascribes the first half to $\mathrm{E}$ as the continuation of $\mathrm{v} .13$ and the second half to $\mathrm{D}$ as a continuation of v. 12. He attributes the first description of salvation in vv. 16-17 to E as the continuation of $14 \mathrm{a}$, and the second in vv. 18-19 to D as the continuation of 14 b (p. 71). For a variation of this division, see Burney (1918:54-55). In contrast to Moore, Lindars (1995:98) argues that neither description forms a whole introduction. Richter (1964:26-40) believes that the entire introduction is from Deuteronomistic redaction and contains later additions from the same school. He believes that v. 13, 17, and parts of 15 and 18 are later additions. He is followed by Soggin (1981:42) and Lindars (1995:98-108. Simpson also believes that the verses should be divided into two sources, which he believes are two different redactors from the same Deuteronomistic school: one source includes 14a, 15b, 16, 17a, and 19b; the second 14b, 15a, 18, 19a. See: Simpson (1957:133-137). Boling (1975:76), in contrast, believes that v. 17 is original, while vv. 18-19 is a later addition. Lindars (1995:102-103) argues that v. 13 is so strange that it cannot be original and is in fact
} 
to this repetition and offer various harmonistic and rhetorical explanations. Kaufmann (1961:95) and Block (1999:124), for example, argue that there is no repetition or addition in vv. $11-13 .{ }^{5}$ nor is the punishment repeated: the mention of the enemy at the beginning of the verse refers to a political government such as Moab, while the "oppressors" at the end of the verse are raiders (Kaufmann 1961:96). The most problematic issue is the repetition and actual contradiction between vv. 16-17 and 18-19. Kaufmann and Sasson believe that vv. 18-19 explicate vv. 16-17. Vv. 18-19 reports that the judges managed to influence the people for short periods of time, while vv. 16-17 describe how the general situation did not improve following the judges' endeavors (Kaufmann 1961:97; Sasson 2014:193). ${ }^{6}$ Amit (1999:55) explains that the objective to present the era in a negative light is expressed through this repetition: the people's evil ways are illustrated with various examples, some repetitive and some complementary. She believes that this repetition is not contradictory; rather, it contributes to the negative tone of the description - sometimes they sin in one way, sometimes in others; sometimes they are oppressed by enemies, sometimes by oppressors; sometimes, the people relapsed into sin while the judge still lived, sometimes immediately after his death. Webb (2012:140-142) also explains the verses in a harmonistic way, showing how the repetitions serve rhetorical purposes. He argues that the repetition of the punishment is structured to show deterioration: they are first raided by plunderers, and then enslaved by enemies (143). Webb also perceives the repetition of the salvation as a description that fully expresses God's mercy on Israel, which is absent in v. 16. Beyond this, Webb believes that these verses describe two different situations: one in which the judge does not move the people to repent (v. 17) and one in which the people temporarily go back to God (144-45).

These two directions are problematic. The scholars' observation that the verses contain repetition is justified, however, the attempts to find various sources within the passage are not convincing. As in many other biblical texts, I suggest that here too, the repetitions and inconsistencies are used as a literary device, that they are employed to express complex meaning. I believe that there are two parallel descriptions that reflect two types of circularity in the era of the judges. ${ }^{7}$

\section{A New Understanding of the complexity of the paradigmatic model}

I believe that inconsistencies and duplication in a text may be an intentional literary device that is meant to create multifaceted ideas. ${ }^{8}$ The subtle repetition of Israel's sin and punishment does not initially seem significant, but the difference between the descriptions of their salvation is salient. There is full repetition in these verses: "Then the Lord raised up judges, who delivered them out of the power of those who plundered

corrupt. The point of the addition is to bring an additional example of worship of "other gods." As for v. 17, Lindars cites Hertzberg, who believes that the point of the addition in this verse is to present Israel's treachery in an even harsher light - that the people do not even obey the judge in his lifetime - and this sketches a portrait of total, continuing disobedience. V. 18 adds the words "When the Lord raised up judges for them," which are added because of the addition in v. 17. If, however, v. 18 is read without its beginning, from the words "when," as the continuation of v. 16, which follows 14, a single, clear sequence emerges.

Block explains that the repetition in vv. 11-13 forms a chiasm.

Richter (1964:98) however, omits v. 17, and similarly Lindars (1995:98).

O'Connell (1996:74-76) presents two variations of the model, but he does not differentiate between their meaning.

$8 \quad$ For this approach, see Assis (2012: 401-414). 
them" (16), followed by repetition of the same motifs: "Whenever the Lord raised up judges for them, the Lord was with the judge, and he delivered them from the hand of their enemies" (18). Each verse is followed by a completely different response. The first time, it states that the people did not listen to the judges and remained rebellious: "Yet they did not listen even to their judges; for they lusted after other gods and bowed down to them. They soon turned aside from the way in which their ancestors had walked, who had obeyed the commandments of the Lord; they did not follow their example" (17). The verse begins with the word "even" ((וגם))). Not only did they fail to obey God, they even ignored the judge who had just saved them. ${ }^{9}$ In contrast, vv. 18-19 describe how the judge moved the people to worship God once more, and this lasted until the judge's death: "all the days of the judge the Lord would be moved to pity by their groaning because of those who persecuted and oppressed them. But whenever the judge died, they would relapse and behave worse than their ancestors, following other gods, worshiping them, and bowing down to them. They would not drop any of their practices or their stubborn ways" (18-19). These are two wildly different portraits of the people's religious situation. The first depicts a stubborn people who cling to their sin, even after their salvation, while in the second, the judge's salvation reminds them of God's ways, and the people continue serving God for the rest of the judge's life. There is no way to mitigate the difference between the two descriptions.

These two descriptions stand in parallel to the two different descriptions of their punishment in v. 14. The first half states that the people are "given over" to "plunderers," (ויתנם ביד שסים), while the second half uses different terminology: they are "sold" to "their enemies" (וימכרם ביד אויביהם):

(14a) So the anger of the Lord was kindled against Israel, and he gave them over to plunderers who plundered them,

(14b) and he sold them into the power of their enemies all around, so that they could no longer withstand their enemies.

The difference between these two descriptions does not seem significant, but Kaufmann (1961:96) has observed that there are references to two different kinds of enemies - the first refers to suffering at the hand of unaffiliated bands of invaders, and the second enslavement by established political bodies. This distinction, however, is significant in light of the two descriptions of the people's salvation - the first, uses the same word, "plunderers" (15), while the second, refers to "enemies" (18). This being the case, we see that there is a significant difference between the people's response to their punishment and that there are two different kinds of oppressors, and the text uses these terms consistently. Following their oppression by "plunderers" (14a) the people are not at all moved by their judge (16:17), while, after being enslaved by their enemies (14b), the people return to follow God for the rest of the judge's life (18-19).

Is there any discernible difference between the descriptions of Israel's sin? So subtle that it has been overlooked by scholars, a careful analysis of the verses shows that the $\sin$, too, is portrayed in two different ways. V. 13 echoes the end of v. 11 and the beginning of v. 12 almost precisely, in reverse order:

9 On this meaning of the word גמג, see BDB, "גמם," p. 169. 
${ }^{11}$ Then the Israelites did what was evil in the sight of the LORD and worshiped the Baals;

12 and they abandoned the LORD, the God of their ancestors...

${ }^{13}$ They abandoned the LORD, and worshiped Baal and the Astartes.

Apparently, the best explanation for the repetition of vv. 11-12 found in v. 13 is that v. 13 provides rhetorical repetition for the sake of emphasis on its severity. Some scholars even point out the envelope structure of the description of the sin and the chiastic arrangement of its components (Boling 1975:74). This explanation would be convincing, were it not for the considerable differences between the descriptions of the punishment and especially of the salvation. These differences require a re-examination of the difference between the two descriptions of sin.

The most striking difference is the order - vv. 11-12 state that Israel first served the Baals and then abandoned God, while in v. 13, they first abandon God and then serve the Baals. This difference is significant if we read the first component, as cause, and the second, as effect. If so, according to the first description, Israel abandoned God because they began serving the Baals; whereas, in the second, because they abandoned God, they began to stray after the Baals. This, then, presents two different portraits: the first being a people who do not necessarily want to betray God, even if their idolatry eventually results in this. Scholars have already pointed out that sometimes Israel was tempted into idolatry - especially Baal worship - but they did not intend to leave God (e.g., Sasson 2014:1995); on the contrary, there were periods when Israel served God and the Baals at the same time, or even served God through Baal worship. This is not forsaking God rather, it is the sin of foreign ritual worship. Baal worship was a powerful temptation in an agricultural society because Baal was the Canaanite rain deity, so when rain was scarce the Israelite farmers were drawn to Baal worship out of desperate need. Essentially, this is not transgression of the first commandment, "I am the Lord your God," but of the second commandment, "You shall not make yourselves a graven image." In contrast, the second description of Israel's sin in v. 13 implies that the people first abandon God and then seek out other deities - not as additional ritual worship, but as an alternative to the God of Israel.

The accuracy of this distinction is confirmed by each description's compatibility with one of the people's responses to the judges' salvation. When the people stray after foreign worship and then leave God (11-12), it makes sense that, when God sends a judge to save the people, they then renounce their idols and come back to God - as long as the judge is alive to remind them of God's power. Once the judge is gone, they are once again tempted into foreign worship, even though they do not mean to forsake their God.

According to v. 13, however, when the people leave God out of sheer rebellion, it then follows that they will not mend their ways even when God sends a judge to save them.

This analysis clarifies that this introduction presents two different models of the people's sin, as can be seen from the following table: 


\begin{tabular}{|c|c|c|}
\hline & $\begin{array}{l}\text { The people are tempted into } \\
\text { Baal worship but then return } \\
\text { to God following their salvation } \\
\text { in } 11-12,14 b-15,18-19 \text { : }\end{array}$ & $\begin{array}{l}\text { The people rebel against God } \\
\text { and will not repent even after } \\
\text { they are saved in } 13-14 a, 16- \\
17 \text { : }\end{array}$ \\
\hline Sin & $\begin{array}{l}{ }^{11} \text { Then the Israelites did what } \\
\text { was evil in the sight of } \\
\text { the LORD and worshiped the } \\
\text { Baals; } \\
\mathbf{1 2} \text { and they abandoned } \\
\text { the LORD, the God of their } \\
\text { ancestors, who had brought } \\
\text { them out of the land of Egypt; } \\
\text { they followed other gods, from } \\
\text { among the gods of the peoples } \\
\text { who were all around them, and } \\
\text { bowed down to them; and they } \\
\text { provoked the LORD to anger. }\end{array}$ & $\begin{array}{l}{ }^{13} \text { They abandoned the LORD, } \\
\text { and worshiped Baal and the } \\
\text { Astartes. }\end{array}$ \\
\hline Punishment & $\begin{array}{l}\mathbf{1 4 b} \text { and he sold them into the } \\
\text { power of their enemies all } \\
\text { around, so that they could no } \\
\text { longer withstand their enemies. } \\
{ }^{15} \text { Whenever they marched out, } \\
\text { the hand of the LORD was } \\
\text { against them to bring } \\
\text { misfortune, as the LORD had } \\
\text { warned them and sworn to } \\
\text { them; and they were in great } \\
\text { distress. }\end{array}$ & $\begin{array}{l}\text { 14a So the anger of the LORD as } \\
\text { kindled against Israel, and he } \\
\text { gave them over to plunderers } \\
\text { who plundered them, }\end{array}$ \\
\hline Salvation & $\begin{array}{l}{ }^{18} \text { Whenever the LORD raised up } \\
\text { judges for them, the LORD was } \\
\text { with the judge, and he delivered } \\
\text { them from the hand of their } \\
\text { enemies all the days of the } \\
\text { judge; for the LORD would be } \\
\text { moved to pity by their groaning } \\
\text { because of those who } \\
\text { persecuted and oppressed } \\
\text { them. } \\
{ }^{19} \text { But whenever the judge died, } \\
\text { they would relapse and behave } \\
\text { worse than their ancestors, } \\
\text { following other gods, } \\
\text { worshiping them, and bowing } \\
\text { down to them. They would not } \\
\text { drop any of their practices or } \\
\text { their stubborn ways. }\end{array}$ & $\begin{array}{l}{ }^{16} \text { Then the LORD raised up } \\
\text { judges, who delivered them out } \\
\text { of the power of those who } \\
\text { plundered them. } \\
{ }^{17} \text { Yet they did not listen even } \\
\text { to their judges; for they lusted } \\
\text { after other gods and bowed } \\
\text { down to them. They soon } \\
\text { turned aside from the way in } \\
\text { which their ancestors had } \\
\text { walked, who had obeyed the } \\
\text { commandments of the LORD; } \\
\text { they did not follow their } \\
\text { example. }\end{array}$ \\
\hline
\end{tabular}


The text presents two variations within the paradigmatic model of sin-punishmentsalvation. In one, the people deliberately forsake God and seek out alternative deities to worship, God sends plunderers to oppress them, and they do not return to God when they are saved. In the second model, the people are drawn to idol worship in addition to their worship of God, which is considered leaving God; their savior motivates them to serve God exclusively once more; but, after the judge's death, they once again relapse into idolatry. The first model is hardly seen in the Book of Judges, while most narratives follow the second model.

In this prevalent model, the people are drawn to the Baals even though they do not mean to abandon the Lord. This is a familiar situation in the Bible-Israel is influenced by the surrounding nations and embraces their polytheism, as seen in Hosea's reproach that the people refer to God as "Baal" (Hos 2:18-19) (e.g., Macintosh 1997:78-79) and Elijah's criticism that Israel must choose between God and Baal (1 Kgs 18:21). Evidence for simultaneous worship was discovered in an inscription from Kuntillet Ajrud containing the phrase, "The Lord and His Asherah" (Meshel 1979:24-34; Andley 2000:104-105). There are various ways of explaining this combination, but, in any case, it certainly points to simultaneous worship of Israel's God and other local deities. A less harsh interpretation of this situation is that the people continue to serve God, but they also adopt local deities under heavy influence from their Canaanite neighbors - a process that is anticipated in Exodus, Numbers, Deuteronomy and Joshua. Israel is criticized for precisely this in the first prologue to Judges.

It is similarly logical that the people once again forsake God with the judge's death. Throughout the judge's lifetime, they are reminded of God's presence and power, but, in the absence of such a reminder, they are drawn to other powers. Another example of this same phenomenon is found earlier in the chapter: "The people worshiped the Lord all the days of Joshua, and all the days of the elders who outlived Joshua, who had seen all the great work that the Lord had done for Israel... and another generation grew up after them, who did not know the Lord or the work that he had done for Israel" (7-10). If those who have witnessed God's salvation firsthand live among the people, all remain faithful to God. Once there are no such living reminders of God's wonders, the people begin to stray. The same is true of the judges themselves: they are human representatives of God and God's salvation, and, if they live, the people feel God's presence and remain loyal. With the judge's death, the people no longer have a physical reminder of God's presence, and they begin to fill this need for substantiality with the ritual worship of Baal, which is characterised by its tangibility. Thus, we can understand the people's need to serve Baal while still intending to remain faithful to the God of Israel.

Scholars have already noted that the Judges narratives effectively implement several variations of this model. Similarly, the observation that there are two variations of the model implies that the narratives will not necessarily fit the models precisely. A model is essentially a generalisation that cannot fit every variation of the model, nor will narratives that represent a certain reality necessarily confirm to its prototype. If this were the case, there would be no need for such a model, whose idea is to overlook the intricacies of each narrative to discern a general pattern.

The general pattern of the Judges narratives is that the people relapse into idolatry after the death of each judge. This is true of the Ehud son of Gera narrative, which opens 
by mentioning Othniel's death (3:11-12), and of the Deborah narrative, where the people's evil ways are explicitly linked to Ehud's death (4:1). The Gideon narrative ends with the report that the people stray back to the Baals after his death (8:33). There are also harsher descriptions in the Judges narratives that conform to the graver paradigmatic model, such as the people's fervor for Baal at the beginning of the Gideon narrative $(6: 29-32)$ or their fierce devotion to idolatry before Jephthah's rule (10:6-7). The enemy that enslaves Israel is usually an established nation, but the enemy in the Gideon narrative is Midian, a nomadic tribe that we might refer to as the "plunderers" of 2:14a, even though this word does not appear in the rest of Judges.

\section{Conclusion}

This analysis implies that this paradigmatic model is not merely a summary of the rest of the Book of Judges; rather, it presents a blueprint that anticipates the complex reality and draws attention to various deviations that are not necessarily salient in the narratives themselves. This is the nature of a good summary, and the Book of Judges' second prologue certainly conforms to this description.

Indeed, the paradigmatic prologue includes two models and introduces two types of transgressions. The first one's theological focus is the necessity of an intermediary between God and the people; this intermediary will demonstrate the presence of God within the people. The death of the intermediator causes a religious crisis. The second model reflects an intentional abandonment of God for the sake of worshiping an alternative deity.

This article also has implications regarding the methodology of biblical literary analysis, demonstrating a fresh way to view complex narratives. While diachronic approaches view inconsistencies, repetitions, and contradictions as indicators of multiple sources from which the text was composed, synchronic approaches attempt to harmonise the tensions within the text. The approach adopted here, is that inconsistencies within a text are used as a literary device intentionally employed to create sophisticated meaning.

\section{BIBLIOGRAPHY}

Amit, Y. 1999. Judges (Mikra Leyisrael). Jerusalem and Tel Aviv: Magnes and Am Oved (Hebrew).

Andley, J.M. 2000. The Cult of Asherah in ancient Israel and Judah: Evidence for a Hebrew Goddess. Cambidge: Cambridge University Press.

Assis, E. (2012) A Literary Approach to Complex Narratives: An Examination of Jos. 3-4, Bibliotheca Ephemeridum Theologicarum Lovaniensium 250: 401-414

Assis, E. 2005. Self-interest or communal interest? An ideology of leadership in the Gideon, Abimelech and Jephthah narratives (Judg. 6-12) (Supplements to Vetus Testamentum, 106). Leiden: Brill Academic Press

Block, D.I. 1999. Judges, Ruth (NIV American Commentary). Nashville: B \& H Publishing.

Boling, R.G. 1975. Judges (AB). New-York: Doubleday.

Burney, C.F. 1918. The Book of Judges. London: Rivingtons. 
Exum, J.C. 1990. The center cannot hold: Thematic and textual instabilities in Judges, $C B Q 52: 410-431$.

Frolov, S. and Stetckevich, M. 2019 repentance in Judges: assessing the reassessment, Hebrew Studies 60: 129-139

Gillmayer-Bucher, S. 2009. Framework and discourse in the Book of Judges, JBL 128:687-702.

Greenspahn, F.E. 1986. The theology of the framework of Judges, VT 36:385-396.

Hoyt, J. 2012. Reassing repentance in Judges, Bibliotheca Sacra 169: 143-158.

Kaufmann, Y. 1961. Sefer Shoftim. Jerusalem: Kiryat Sefer (Hebrew).

Lindars, B. 1995. Judges 1-5: A new translation and commentary. Edinburgh: T \& T Clark.

Macintosh, A.A. 1997. A critical and exegetical commentary on Hosea (ICC). Edinburgh: T \& T Clark.

Meshel, Z. 1979. Did Yahweh have a consort? The new religious inscriptions from Sinai, Biblical Archaeology Review 5(2):24-34.

Moore, G.F. 1895. A critical and exegetical commentary on Judges (ICC). Edinburgh: T \& T Clark.

O'Connell, R.H. 1996. The rhetoric of the Book of Judges (VTSup, 63). Leiden: Brill.

Richter,W. 1964. Die Bearbeitungen des "Retterbuches" in der deuteronomischen Epoche (Bonner Biblische Beiträge, 21). Bonn: P. Hanstein.

Sasson, J.M. 2014. Judges 1-12 (AB). New Haven: Yale University Press.

Schneider, T.J. 2000. Judges (Berit Olam), Collegeville: Liturgical Press.

Simpson, C.A. 1957. Composition of the Book of Judges. Oxford: Basil Blackwell.

Soggin, J.A. 1981. Judges: A commentary (OTL). London: SCM.

Trompf, G.W. 1979. Notions of historical recurrence in classic Hebrew historiography, Studies in the historical books of the Old Testament, (VTsup, 30), Leiden: Brill, pp. 213-229.

Webb, B.G. 1987. The Book of the Judges: An integrated reading (JSOTsup, 46) Sheffield: Sheffield Academic Press.

Webb, B.G. 2012. The Book of Judges (NICOT). Grand Rapids: Eerdmans. 